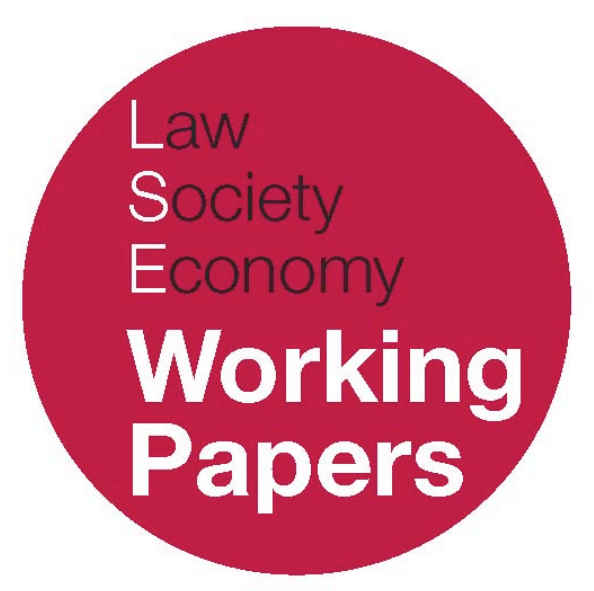

\title{
Fairness, Consensus, and the Justification of the Ideal Liberal Constitution
}

\author{
Philip Cook
}

LSE Law, Society and Economy Working Papers 4/2009

London School of Economics and Political Science

Law Department

This paper can be downloaded without charge from LSE Law, Society and Economy Working Papers at: www.lse.ac.uk/collections/law/wps/wps.htm and the Social Sciences Research Network electronic library at: http://ssrn.com/abstract=1331374.

(C) Philip Cook. Users may download and/or print one copy to facilitate their private study or for non-commercial research. Users may not engage in further distribution of this material or use it for any profit-making activities or any other form of commercial gain. 


\title{
Fairness, Consensus, and the Justification of the Ideal Liberal Constitution
}

\author{
Philip Cook $^{*}$
}

\begin{abstract}
In Constitutional Goods Brudner argues that the justification of the ideal liberal constitutional must be based on an alternative conception of public reason from that that presented by Rawls in Political Liberalism. This paper sets out the disagreement between the two notions of justification, and argues that Brudner's proposed account is problematic on two accounts. Firstly, it seems internally inconsistent. Brudner's alternative to Rawls's overlapping consensus, a convergent consensus on an inclusive conception of liberalism, will be impossible given the plural and often contradictory nature of differing liberal doctrines. Secondly, even if such a consensus is possible it will be characterized by modus vivendi rather than a reasonable agreement based on the value of fairness. Consequently, Brudner's notion of public justification will lack both fairness and consensus, and should therefore be rejected as the basis for the ideal liberal constitution.
\end{abstract}

\section{INTRODUCTION}

In Constitutional Goods, ${ }^{1}$ Alan Brudner seeks to articulate a novel conception of justice that will inform the content of the ideal liberal constitution. The content and justification of this conception of justice are the topics of this paper. The content of this novel conception of justice is constituted by what Brudner

\footnotetext{
* London School of Economics. Thanks to participants at the LSE Forum in Legal and Political Theory Symposium for comments and contributions on an earlier draft, and in particular to Alan Brudner for his generous and comprehensive contributions at the symposium. This paper is part of a collection of essays examining important aspects of Constitutional Goods (Oxford: Oxford University Press, 2004). It first appeared as a paper presented at a symposium organized by the LSE Legal \& Political Theory Forum and hosted at the London School of Economics on 9-10 May, 2008. A revised version of this article is published in the current issue of the Canadian Journal of Law and Jurisprudence (2009) 1. The organizers, Philip Cook and Thomas Poole, would like to thank both the LSE and the LSE Law Department for supporting this event.

1 A. Brudner, Constitutional Goods (Oxford: Oxford University Press, 2004).
} 
describes as an inclusive conception of liberalism, and its justification is grounded on an account of public reason that is presented in opposition to Rawls's. I will argue that we should reject both the content and justification of Brudner's conception of justice. In sum, I will argue that Brudner cannot construct an inclusive conception of liberalism from elements of libertarianism, egalitarianism, and communitarianism, and that his account of public reason lacks the properties of fairness and reciprocity that differentiate a reasonable agreement from a modus vivendi. This paper therefore seeks to defend a Rawlsian political conception justice and justification from Brudner's criticisms and proposed alternatives.

Constitutional Goods is a work of great breadth and depth, and deserves careful consideration from political philosophers for its many original and controversial arguments regarding the ideal liberal constitution. I leave open the question of whether Brudner's ideal liberal constitution and its goods should be endorsed by liberals, and whether the more Rawlsian political conception of justice and justification I defend here could harmonise with this constitution. However, is seems to me that Brudner's inclusive conception of liberalism and his account of public reason pose significant challenges to political liberals, challenges which I believe it is important to meet.

The paper begins with a brief description of Brudner's account of the inclusive conception of liberalism, and then in sections two and three sets out Brudner's criticisms of Rawls's political liberalism and his alternative account of public reason respectively. In section four I consider Brudner's rejection of Rawls's distinction between political and comprehensive doctrines, and argue that either the various liberal paradigms as described by Brudner are political doctrines, in which case his too is a political conception of justice, or they are comprehensive and he fails to address the problem of reasonable pluralism. In section five I address Brudner's proposal of a convergent consensus in place of an overlapping consensus, and argue that a convergent consensus is improbable on the terms he sets out. In section six I argue that even if my objections can be met, any consensus on Brudner's terms would fail to include elements of fairness that distinguish a reasonable agreement from a modus vivendi. I conclude that Brudner's conception of justice and justification suffers from internal problems combined with properties that make it unattractive from a liberal point of view.

\section{PARADIGMS OF THE LIBERAL CONFIDENCE AND THE INCLUSIVE CONCEPTION}

One of the most impressive features of Constitutional Goods is its attempt to provide a justification of the ideal liberal constitution that embraces all views that share in 'the liberal confidence.' 2 The liberal confidence involves three commitments:

2 ibid at 13-15. 
firstly, that the individual human agent is of final value, and that this value is indefeasible by any other value or purpose; secondly, that the value of the human agent is intrinsic, and not derived from membership of a group or participation in a culture; and thirdly, that the value of the human agent creates inviolable constraints on the permissibility of subordinating the agent's ends to those of other individuals or entities such as states or nations. Brudner argues that the liberal confidence is shared by a wide range of liberal paradigms, including the libertarianism of Hayek and Nozick, the egalitarianism of Rawls and Dworkin, the communitarianism of Taylor and Sandel, and the perfectionism of Finnis and MacIntyre. ${ }^{3}$ Whilst this liberal confidence is shared by a broad range of liberal paradigms, Brudner argues that the egalitarian paradigm has become the dominant liberal conception of justice in terms of which contemporary liberal constitutionalism is justified in both theory and practice. Brudner argues that the liberal egalitarian conception of justice is at once too partisan and too thin to provide an adequate foundation for the ideal liberal constitution. It is too partisan because the other liberal paradigms that share the liberal confidence are excluded from the framework of justification of the liberal constitution as the justification draws on values they do not endorse. Consequently, the legitimacy of a liberal egalitarian constitution is compromised by its exclusion of all other liberal paradigms that are denied the scope to assent to its authority. The liberal egalitarian constitution is too thin because its prioritisation of the right over the good prevents it from recognising that certain goods can trump basic liberal egalitarian rights in a manner entirely consistent with the liberal confidence. Brudner argues that trumping goods such as marriage, religious practice, and membership of corporations, are necessary to the flourishing of an ideal liberal polity, and are in fact becoming recognised as such in existing constitutional practice in various liberal regimes. ${ }^{4}$ As a partisan version of liberalism that dogmatically prioritises the right over the good, the egalitarian constitution is unable to provide a normative justification of current liberal constitutional practice, and to provide a basis for a flourishing liberal polity.

Whist Brudner believes that current theoretical and constitutional practice is deficient because of its commitment to egalitarianism at the expense of other liberal paradigms, his complaint is less with egalitarianism than with the idea that any particular paradigm of liberalism can provide the basis for a stable and legitimate liberal polity. A libertarian constitution or communitarian constitution would suffer from the same problem of partiality as does the egalitarian constitution. Brudner consequently argues that the basis of the justification of the ideal liberal constitution must be wrought on entirely different grounds than offered hitherto. He begins the presentation of his alternative with a diagnosis of

\footnotetext{
3 ibid, ix.

${ }^{4}$ Brudner points to the examples of the constitutions of Canada, South Africa, and Germany, ibid, 21.
} 
the problems with Rawls's version presented in Political Liberalism and subsequent works. ${ }^{5}$

\section{BRUDNER'S COMPLAINT WITH RAWLS'S POLITICAL LIBERALISM}

On Rawls's view, citizens exercising their theoretical and practical reason freely in a liberal polity will develop divergent comprehensive doctrines on important moral, religious, and philosophical questions. The stability and legitimacy of a wellordered liberal society relies on the possibility of finding grounds for the public justification of a political conception of justice ${ }^{6}$ that appeals to shared political values, rather than conflicting comprehensive doctrines, and this in turn relies on the reasonableness of citizens. Reasonable citizens are those who are motivated to agree to terms of social cooperation that are acceptable to others in society who are similarly motivated, and who accept the burdens of judgment on the justification of a public conception of justice. Citizens who accept the burdens of judgment acknowledge that theoretical and practical reasoning are limited by such conditions as lack of perfect information, the fuzziness of many theoretical and practical concepts, the affect of personal experience on the evaluation of evidence, and natural differences in importance individuals attach to various goals. Given that the conception of justice governs those institutions that have a fundamental and pervasive effect on society, and given that this effect is enforced through the coercive power of the state, Rawls argues that the justification of the conception of justice must be grounded on values and norms of reasoning that are publicly accessible and endorsed by all reasonable citizens. Thus, esoteric arguments and theories, convoluted modes of argumentation, and controversial evidence are unacceptable sources for a public justification. Public justification requires public reason, which appeals to common sense, accepted evidence, and shared norms of argumentation. Rawls argues that through the exercise of public reason, reasonable citizens will seek an overlapping consensus on the political conception of justice that governs the basic structure of society. The overlapping consensus will refer to the principles for the distribution of primary goods, and their justifying reasons. Reasonable citizens will endorse the overlapping consensus for reasons coherent with their own comprehensive doctrines, but this endorsement must also cohere with public reason. Its coherence with public reason allows such a justification of a political conception of justice to be freestanding, as it relies on no particular comprehensive doctrine. Thus Rawls argues that a freestanding political

\footnotetext{
5 See J. Rawls, Political Liberalism (New York: Columbia University Press, 1993); J. Rawls, "The Idea of Public Reason Revisited" (1997) 64 The University of Chicago Law Review 765-807; J. Rawls, Justice as Fairness: A Restatement (Cambridge, Ma.: Harvard University Press, 2001).

6 A political conception of justice is a moral conception of justice that applies to the fundamental economic, democratic, and legal institutions of society that comprise the basic structure.
} 
conception of justice can be justified on grounds of public reason to all reasonable citizens who are members of a liberal polity that is marked by permanent reasonable pluralism.

In common with Rawls, Brudner seems to accept that it is quite natural for a liberal society to be composed of a plurality of divergent doctrines that hold differing views on important matters of philosophy, ethics, and religion. We encountered such a plurality in the earlier description of the variety of liberal paradigms present in theory and practice of liberal politics. However, Brudner rejects Rawls's notion of a public justification of an overlapping consensus on a freestanding political conception of justice. Brunder's objections focus on Rawls's notions of a freestanding conception of justice, the overlapping consensus, and the burdens of judgment.

\section{Freestanding Conception of Justice}

Brudner argues that Rawls's notion of a freestanding conception of justice results from an undue pessimism about the possibility of finding a basis for the public justification of a conception of justice on terms internal to the various liberal paradigms. Any attempt at public justification that fails to provide reasons that can be endorsed from within the differing liberal paradigms will fail, because the supposed freestanding conception will necessarily be either too empty and formal to provide substance to the conception of justice, or too thick and partisan to provide a shared basis for acceptance. In other words, if truly freestanding from any of the reasons and values that give substance to the various liberal paradigms, a political conception of justice will be unable to provide content to the important political rights and principles of an ideal liberal constitution. How are property rights to be conceived without a substantive conception of entitlement to property, the conditions of transfer, and the basis for contract and labour? However, Brudner argues that any substantive account of these or any other rights will necessarily be derived from a particular version of the liberal confidence that will be unacceptable to the other paradigms. Such substance will be necessarily partisan, on Brudner's view, because Rawls has disavowed the possibility of a substantive political conception of justice that includes essential elements of each liberal paradigm in favour of a conception that is freestanding of any particular liberal doctrines. These problems of the formality and partiality of the freestanding political conception of justice threaten the stability and legitimacy of a liberal polity.

\section{OverLaPPing Consensus}

For Rawls, the agreement characterised by an overlapping consensus on a freestanding political conception of justice differs markedly from a modus vivendi. A modus vivendi is agreement contingent on the self-interest of the citizens justified from the point of view of their comprehensive doctrines. The overlapping 
consensus, on the other hand, is agreement motivated by reasonableness rather than self-interest. For Rawls, to be motivated by reasonableness means to be motivated to seek agreement according to reasons and values that are mutually authoritative to all other reasonable persons. These reasons and values are therefore shared, and as such are neither self-interested nor altruistic. They are not self-interested because they do not refer to reasons and values that are grounded in a person's particular goals and motivations, and they are not altruistic because they do not assume a sacrifice or negation of self-interest as the basis for agreement. But Brudner argues that the overlapping consensus must collapse into a modus vivendi. It collapses because '...the reasons supporting the consensus are external to the conception of public reason that generated the principles in the first place, [and] it will be a sheer accident if all the principles are derivable from a particular philosophic view, or congruent with it, or compatible with it. ${ }^{7}$ I understand Brudner's point to be that as the political conception of justice is freestanding, all justifications of it are independent of each liberal paradigm, and therefore any overlap between liberal paradigms and the conception will be ad hoc. Consequently, any consensus will not be on the basis of reasonableness but on an accidental coincidence between the partisan interests of a particular liberal paradigm and the political conception of justice. Therefore, the distinction between an overlapping consensus and modus vivendi will evaporate.

\section{BURDENS OF JUDGMENT}

We recall that for Rawls a reasonable citizen is committed to seek terms of agreement that are neither self-interested nor altruistic but mutually authoritative, and who also recognises the burdens of judgment. Having rejected Rawls's arguments for an overlapping consensus derived from the motivation to seek reasonable agreement, Brudner also rejects Rawls's view that the burdens of judgment constrain and constitute public justification. Brudner argues that Rawls's commitment to the burdens of judgment is derived from a view of judgment where there is an inevitable indeterminacy between a concept and its application. ${ }^{8}$ This indeterminacy is the product of two phenomena: firstly, that individuals are inevitably imperfectly informed, influenced by subjective experience and disposition, and naturally weigh evidence and outcomes differently; secondly, indeterminacy is the product of the nature of the faculty of judgment itself, where there is no higher-order rule for the application of rules to particular cases, as this leads to an infinite regress in rules of application. However, Brudner points out that this view of judgment as riven by indeterminacy is merely one conception. Brudner seems to accept that certain kinds of judgment are characterised by such indeterminacy, but offers an alternative notion of judgment appropriate to public reasoning. This alternative notion of judgment is characterised by a comparison of

7 n 1 above, 19.

8 ibid, 432 . 
the conception of justice endorsed by a particular liberal paradigm (such as libertarianism, egalitarianism, and communitarianism) with an account of political authority that would exist in a society that fully realised the particular liberal paradigm's conception justice. For example, we identify the integral features of an egalitarian conception of justice, which according to Brudner are the principles of luck egalitarianism. We then imagine a society and its constitution that fully realised the egalitarian conception of justice. Brudner argues that such a society and its constitution would fail to fully protect the rights of individuals and promote goods necessary to the fulfilment of an egalitarian society. This process of comparison of the conception of justice and its full realisation in a political society leads to an identification of the contradictions and omissions in each liberal paradigm that are addressed by properties of the other liberal paradigms. The outcome of this process of public reasoning freed from the burdens of judgment is Brudner's key idea of the inclusive conception of liberalism: a conception of justice that is not freestanding but rather constituted by particular features of each liberal paradigm that together offer a full conception of justice that each can endorse on its own terms and which consequently receives unanimous consent. We will say more about Brudner's inclusive conception of liberalism and his proposed method of justification presently, but for the moment it is sufficient to note that Brudner's objection to Rawls's notion of the burden's of judgment is not that it is flawed or mistaken, but rather that it is inappropriate to public reasoning and inferior to his proposed alternative.

Brudner therefore argues that there are good reasons to doubt that Rawls's notion of a public justification in the form of an overlapping consensus on a freestanding political conception of justice will provide a basis for the justification of an ideal liberal constitution. On Brudner's view, the stability and legitimacy of the ideal liberal constitution does rely on a public justification, but he presents a novel alternative to Rawls's version. This is his notion of a convergent consensus on an inclusive conception of liberalism.

\section{THE CONVERGENT CONSENSUS ON THE INCLUSIVE CONCEPTION OF LIBERALISM}

We saw that Brudner criticises Rawls's notion of an overlapping consensus as inevitably collapsing into a modus vivendi. Brudner believes that a stable principled justification of the ideal liberal constitution must include essential elements of the differing conceptions of justice of each liberal paradigm. One of the fascinating aspects of Constitutional Goods is Brudner's development of the inclusive conception of liberalism from the three main liberal paradigms. Through historical and philosophical analysis, Brudner presents an account of how each liberal paradigm develops its core moral and political commitments, and how both in theory and practice each paradigm proves incomplete without the contribution of 
elements of the others. In the broadest outline, Brudner argues that the problem of legitimate political authority raised by the decline of deference to the received authority of monarchs and churches led to the development of the libertarian commitment to the intrinsic value of individuals and the rights that protect that individual and their choices. Thus the foundation stone of liberalism was laid, and authority is associated with consent. However, Brudner argues that the libertarian paradigm cannot fulfil its own ambitions of providing a full account of legitimate authority. Whilst legitimacy is associated with consent, the libertarian conception of choice omits an account of the quality of that choice. Is the choice free from manipulation, adequately resourced, and likely to be fulfilled? Brudner argues that the libertarian paradigm does not have the conceptual resources to provide answers to these questions, and so whilst its commitment to the relationship between the value of individual choice and legitimacy is retained, the conception of justice which fully accounts for legitimacy and stability requires augmentation. This augmentation is provided by the egalitarian paradigm which seeks to answer the questions of the quality of choice with an account of the distribution of goods necessary to allow all individuals effective choice and therefore to be able to provide consent. Thus, the egalitarian paradigm enriches the account of the necessary context and conditions for the possibility of autonomous choice for each individual. In particular, the egalitarian paradigm provides the key conceptual distinction between choice and chance, upon which decisions of just distribution are made. ${ }^{9}$ However, Brudner argues that the account of choice that gives substance to the notion of legitimate authority also requires an answer to what ends the choices of individuals should aim at, how these personal ends should be related to the ends of the society in which individuals live, and how the value of these ends should be weighted against the value of the rights of the individuals to choose them. The answers to these questions are found in the communitarian paradigm of liberalism, which explains why institutions such as family, community, polity, and the components of these such as marriage and membership of corporations are of moral and political value. These goods are a necessary condition for the possibility of a community of individuals who are able to exercise free choice and therefore express consent. The full account of the conception of justice that provides the basis for legitimate authority must therefore include elements of each liberal paradigm in an inclusive conception of liberalism. The ideal liberal constitution enumerates the rights and goods necessary to the flourishing of the ideal liberal polity, and the core goods of the communitarian paradigm may trump certain of the individual rights when their preservation and promotion is required to secure the basis for free individual choice and consent. Thus, the ideal liberal constitution embodies a balance of reciprocally related rights and goods, which are in a dynamic relationship of priority, which Brudner describes as sequential rather than lexical. ${ }^{10}$

\footnotetext{
${ }^{9}$ Brudner has in mind luck egalitarian variant of egalitarianism. See ibid, 254-276.

10 ibid, 22.
} 
Brudner argues that this inclusive conception of liberalism can provide a convergent rather than an overlapping consensus. We recall that Rawls's overlapping consensus was characterised by principled reasonable agreement on the freestanding conception of justice. Rawls argues that reasonable individuals will affirm both the freestanding political conception of justice and their particular comprehensive doctrines. Some highly systematic comprehensive views will include the political conception in their framework of reasons and values, but it is not a requirement that comprehensive doctrines integrate the political conception of justice into their comprehensive doctrine. Indeed, one of the main goals of Rawls's argument is to show that the political conception of justice has reasons and values of its own that provide sources of justification freestanding of any particular comprehensive doctrine. Thus, the agreement/justification reached on the political conception of justice will overlap all those citizens and their comprehensive doctrines that affirm the freestanding political conception of justice on reasonable grounds. We saw that Brudner argues that this will fail to provide a principled reasonable agreement and will collapse into a modus vivendi because the various reasonable comprehensive doctrines will (mostly) not endorse the political conception of justice for reasons internal to their systems of beliefs and values, and this lack of grounding in the comprehensive doctrines will lead to an ad hoc consensus that will fail to provide stability and legitimacy. In order to provide for the stability and legitimacy required of a full account of the justification of the political conception of justice, Brudner argues that the agreement of all reasonable comprehensive views (which for him would be members of the family of one of the liberal paradigms) must be internal to their framework of reasons and values. In other words, the political conception of justice is justified to libertarians because it protects the individual's rights that libertarianism contributes to the inclusive conception; it is justified to egalitarians because it provides for the distribution of social goods; and it is justified to the communitarian because it promotes the goods necessary to the reciprocal flourishing of individuals and society in the dialogic community. Therefore, the justification of the ideal liberal constitution is the result of a convergence of the differing paradigms of liberalism. This consensus converges on the inclusive conception which is not freestanding of any of these particular liberal paradigms, but is rather constituted by a combination of elements of each. This, Brudner argues, addresses the problems he raised with Rawls's argument for an overlapping consensus on a freestanding political conception of justice, as it provides for a principled agreement from within each liberal paradigm that is acceptable to all from with their particular doctrines. Thus, Brudner argues that the convergent consensus on the inclusive conception of liberalism is the most appropriate basis for the stability and legitimacy of the ideal liberal constitution.

Having outlined Brudner's approach to the justification of the ideal liberal constitution, and his differences with Rawls, we will now consider whether it does provide a more appropriate basis for the justification of the ideal liberal constitution. We will first examine Brudner's portrayal of the liberal paradigms, we 
will then assess the convergent consensus on the inclusive conception, and finally ask whether Brudner's view can provide the basis for a principled agreement on the ideal liberal constitution.

\section{THE PORTRAYAL OF THE LIBERAL PARADIGMS}

We recall that one of the motivations for Constitutional Goods is to set out an account of the justification of a political conception of justice that is neither too formal nor too partisan. To achieve this Brudner seeks to show how the different paradigms of the liberal confidence can find agreement from within the framework of their own reasons and values. This agreement forms the convergent consensus on the inclusive conception of liberalism. As the convergent consensus of the inclusive conception provides the basis for the justification of the ideal liberal constitution, the content of the member paradigms is crucially important as these, in combination, constitute the inclusive conception. Therefore, Brudner's portrayal of these member paradigms matters greatly to the justification of the ideal liberal constitution. However, it seems to me that the portrayal of the liberal paradigms is problematic on two counts. Firstly, Brudner's description of the content of each paradigm is partial and fails to recognise the complex and contradictory relationship between differing positions with libertarianiam, egalitarianism, and communitarianism. Secondly, if liberal paradigms do not exist in the manner suggested by Brudner's portrayal, the notions of the convergent consensus on the inclusive conception, and the subsequent constitutional goods, seem threatened.

\section{The Competing and Contradictory Nature of the Liberal PARADigms}

Brudner's portrayal of each liberal paradigm is controversial to members of each paradigm. Take the example of the egalitarian paradigm. Brudner's account of the egalitarian paradigm is based on the assumption that egalitarianism is concerned to distinguish choice from chance, and allocate responsibility and resources on the basis of compensating for disadvantages that are the result of bad luck. Only inequalities that are the result of an individual's choices may be allowed. This is the luck egalitarian conception of egalitarian.

One minor objection is to the association of both Dworkin and Rawls with this conception of egalitarianism. As I understand Dworkin's work on equality, it is motivated by Rawls's underdeveloped account of the affect of different kinds of luck on distributions. To state the difference, take two cases. In case A, Jenny is born with a severe disability that prevents her from earning a living, whilst Johnny is born healthy and clever and develops a successful career. In case B, Jenny and 
Johnny are born with equal talents and resources. Jenny squanders her talents and resources and ends up poor, whilst Johnny works hard, chooses wisely, and ends up wealthy. Rawls would argue that unless the inequalities were to the benefit of Jenny in both cases (and let's assume for this argument that they are not), then both unequal distributions are unjustified and should be corrected. Dworkin on the other hand wishes to draw a distinction between unchosen bad luck, and chosen bad luck. ${ }^{11}$ This distinction is expressed in his account of brute luck and option luck. Dworkin would argue that an egalitarian society would find case A impermissible, and case B permissible. Therefore, it seems important to distinguish both Dworkin and Rawls's view of the relationship between choice and chance and egalitarianism. Whilst this is, in one respect, a minor interpretative point regarding varieties of egalitarianism, it points to a much more significant problem with Brudner's portrayal of the egalitarian paradigm.

Brudner describes the egalitarian paradigm as equivalent to luck egalitarianism. However, luck egalitarianism is not equivalent to liberal egalitarianism. The debate about the nature and value of equality admits of no consensus. The debates between supporters of sufficiency, ${ }^{12}$ priority, ${ }^{13}$ luck egalitarianism, ${ }^{14}$ and strict egalitarianism ${ }^{15}$ would each contend that they best account for egalitarianism. Moreover, many of these views are mutually exclusive: for example strict egalitarianism excludes the kinds of inequalities allowed by prioritarianism and luck egalitarianism. Brudner might respond that not all of these views are properly described as egalitarian (for example prioritarianism or sufficiency), and he is only concerned with the essential commitments of the egalitarian paradigm as it features in a development of the inclusive conception. But if Brudner is concerned to identify the essential commitments of the egalitarian paradigm, the closest fit would be Temkin's strict egalitarianism. Temkin's is perhaps the purest egalitarianism because it focuses on the value of equality as the comparative standing of agents and denies that the levelling down objection negates this value. It seems unlikely that luck egalitarianism could provide the basis for an account of the egalitarian paradigm, as luck egalitarianism is only one partial view within this complex debate. The same problem attaches to the libertarian paradigm. Perhaps Nozick and Hayek would be eligible members of the libertarian paradigm and Brudner sets out, but left-libertarians such as Hillel Steiner, ${ }^{16}$ Peter Vallentyne ${ }^{17}$ and Michael Otsuka ${ }^{18}$ or the conscience libertarian

\footnotetext{
${ }^{11}$ R. Dworkin, 'What is Equality? Part 2: Equality of Resources' (1981) 10 Philosophy and Public Affairs 283.

12 For example see E. Anderson 'What is the Point of Equality?' (1999) 109 Ethics 287, and H. Frankfurt 'Equality as a Moral Ideal' (1987) 98 Ethics 21.

${ }^{13}$ For example T. Nagel, Equality and Priority (New York: Oxford University Press, 1991).

14 R. Dworkin, Sovereign Virtue (Cambridge, Ma.: Harvard University Press, 2000) and G. A. Cohen, If You're an Egalitarian, How Come You're So Rich? (Cambridge, Ma.: Harvard University Press, 2000).

15 L. Temkin, Inequality (New York: Oxford University Press, 1993) and L. Temkin, 'Harmful Goods, Harmless Bads', in R.G. Frey and C. W. Morris (eds), Value, Welfare, and Morality (Cambridge: Cambridge University Press, 1993).

16 H. Steiner, An Essay on Rights (Oxford: Blackwells, 1994).

17 P. Vallentyne, 'Libertarianism and the State' (2007) 24 Social Philosophy and Policy 187.

18 M. Otsuka, Libertarianism without Inequality (Oxford: Clarendon Press, 2003).
} 
Chandran Kukathas ${ }^{19}$ would surely dispute this equation of libertarianism with the right-libertarianism of Nozick and Hayek. The foundational commitments of these other libertarians are at odds with the foundations of Nozick and Hayek, as their quite opposed views on the origin and nature of property reveal. In portraying a liberal paradigm in terms of a particular partisan position, Brudner seems to neglect the competing and contradictory nature of the plural views of likely members of that paradigm.

\section{CAN THE InClusive ConCEPTION SuRvive CoMpleXity?}

The objection that Brudner has failed to recognise the competing and contradictory nature of the liberal paradigms seems to have one of two implications. Either, Brudner needs to provide a more convincing argument to other members of the paradigm of why one particular partisan view should be taken as definitive. For example, egalitarians are owed a stronger account of why luck egalitarianism should be taken as the essence of the egalitarian paradigm rather than strict egalitarianism or prioritarianism and so on. Perhaps this can be done. However, if it turns out that strict egalitarianism is in fact the essence of the egalitarian paradigm, or some other variant like prioritarianism, this has significant implications for his theory. The theory of constitutional goods depends on the account of the inclusive conception. If the members of the inclusive conception are different in substance, we would plausibly arrive at a different set of constitutional goods. So perhaps the form of theory would survive, but it would be necessarily different in substance, as the inclusive conception would be substantively different and alternate goods would be required to support such a different conception. A second implication is that once the diverse and contradictory nature of the liberal paradigms is recognised, the inclusive conception of liberalism becomes impossible. I have suggested that the notion of member liberal paradigm rests on the assumption that candidate positions can be reduced to certain thin commitments. I have argued above in reference to egalitarianism and libertarianism that even different members of the same family of liberal views are mutually exclusive. If the theoretical and normative premises of prioritarianism, strict egalitarianism, and luck egalitarianism are incompatible, there cannot be such doctrines as liberal paradigms. Consequently, the crucial notion of overlapping convergence on the inclusive conception cannot arise, as there are no paradigms which can converge. There are only multiple different contradictory egalitarianisms, libertarianisms, and communitarianisms.

\footnotetext{
${ }^{19}$ C. Kukathas, The Liberal Archipelago (Oxford: Oxford University Press, 2003).
} 


\section{LIBERAL PARADIGMS AND THE POLITICAL/COMPREHENSIVE DISTINCTION}

We saw earlier that one of Brudner's objections to Rawls's public justification of a political conception of justice was that Rawls denies the possibility of a principled agreement between the plurality of reasonable comprehensive doctrines that will provide stability and legitimacy for the liberal polity. Brudner proposes that liberal paradigms can converge on a consensus on the inclusive conception of liberalism. This convergence then allows each member paradigm to endorse the conception of justice from within their own doctrine, rather than from the perspective of an overlapping consensus on a freestanding political conception of justice. It seems clear that Brudner regards the liberal paradigms as kinds of comprehensive doctrines.

Since, moreover, any philosophic agreement among liberalisms must be an agreement among liberal philosophies, we must also reopen the question whether a political conception of justice must be free-standing of all comprehensive moral views. Rawls insists that it must be, but nothing in the idea of a political conception, which is just a conception whose justification is directed to a limited audience, requires that it be detached from a comprehensive moral philosophy. 20

Three questions arise from Brudner's association of liberal paradigms with comprehensive doctrines: firstly, are they truly comprehensive; secondly, is Brudner's convergent consensus comprehensive or political in nature; and thirdly, does Brudner's conception of doctrines address the problem of reasonable pluralism?

\section{Are Liberal Paradigms Comprehensive Doctrines?}

Brudner's portrayal of the libertarian, egalitarian, and communitarian liberal paradigms makes it clear that they are certainly broader than the political doctrines Rawls has in mind. A political doctrine, from Rawls's point of view, is defined in terms of its object. In other words, a political doctrine is a doctrine regarding the political conception of justice that is concerned with principles that govern the fundamental institutions of society and their effects on stability, legitimacy, and the distribution of social goods. Comprehensive doctrines include both theoretical and practical philosophical commitments, that is views on such things as natural science, ontology, theology, and morality. These doctrines need not be set out in overtly philosophical terms, but they refer to a range of objects that exceed (although may also include) the boundaries of the basic structure of society. To fix the idea of comprehensive doctrines, we may suggest obvious candidates such as

20 n 1 above, 10. 
Roman Catholicism and secular humanism. Now it seems clear that the liberal paradigms that are members of the inclusive conception are not comprehensive in this manner. Libertarianism, egalitarianism, and communitarianism, as set out by Brudner, do not include metaphysical, ontological, or theological commitments (at least not integrally). Brudner might respond that whilst they are not fully comprehensive, they are not strictly political views and are far more philosophical (by which he seems to imply comprehensive in nature) in their commitments. As evidence, he may point to his discussions of the conception of the person in libertarianism, the commitments to views on choice and responsibility in egalitarianism, and society and culture in communitarianism. However, as Rawls points out in The Independence of Moral Theory, ${ }^{21}$ philosophical commitments to notions of causality and conceptions of the person and society are independent of practical questions of morality and politics. They are independent in the sense that any given conception of personal identity or causality or social formation is compatible with a diverse range of moral theories such as perfectionism, utilitarianism, Kantian constructivism, and intuitionism. And so it is not the libertarian's conception of the person, or the egalitarian's conception of causality, or the communitarian's conception of social formation that grounds their particular moral and political commitments. These particular moral and political commitments are grounded on responses to practical moral and political questions, and draw on reasons and values that relate to these practical and not theoretical problems. Therefore, whilst Brudner is no doubt correct that the libertarian paradigm, the egalitarian paradigm, and the communitarian paradigm take positions on certain broader philosophical issues, these philosophical positions are not constitutive of these paradigms, but are philosophically independent of them. We can therefore argue that the various liberal paradigms are not comprehensive or philosophical in the sense of which Rawls is concerned with comprehensive doctrines.

\section{Is the Convergent Consensus Comprehensive or Political?}

One of Brudner's aims in Constitutional Goods is to present an account of the justification of the ideal liberal constitution that is neither formal nor partisan, both of which qualities threaten Rawls's Political Liberalism. The justification of the ideal liberal constitution proposed by Brudner aims to show how the broad philosophical commitments of the liberal paradigms may converge on an inclusive conception and therefore find grounds to justify a liberal conception of justice from within their particular liberal paradigms. We have seen that Brudner characterises this as a convergent consensus of liberal philosophies on a nonfreestanding conception of justice. I have just argued that the liberal philosophies as set out by Brudner are not truly comprehensive. They are political conceptions,

21 J. Rawls, 'The Independence of Moral Theory' (1974 - 1975) 48 Proceedings and Addresses of the American Philosophical Association 5. 
because the object of their reasons and values is political. Their reasons refer to the rules and authorities that, in the paradigm's view, should govern political interactions. In the case of libertarianism these rules include the impermissibility of the violation of private property; in the case of egalitarianism, the authority of individual reason in making independent choices with sufficient resources; and in the case of communitarianism, the authority of corporate associations. The object of these rules, values, and authorities is political because it concerns the nature of political rights and the goods of association. Even the discussion of the role of religion in the ideal liberal constitution is treated in its guise as a constitutional good, not as a salvific or redemptive good. ${ }^{22}$ It seems then that the kind of consensus that Brudner achieves through his portrayal of liberal paradigms and their convergence on the inclusive conception is political and not comprehensive or philosophical as he suggests. Is Brudner's conception freestanding also?

Rawls describes his political conception as freestanding because it does not rely on any particular comprehensive view for its constitution and justification. Its content and justification is explicable in terms internal to the political conception of justice itself, which means that its object and the reasons that justify it are political, and not metaphysical, ontological, or theological. The conception of justice that Brudner proposes, which is constituted by the convergent consensus on the inclusive conception of liberalism, seems similarly freestanding. It is certainly true that the different liberal paradigms are mutually constitutive of the inclusive conception, so it is clearly not freestanding of them. But as I have suggested above, these liberal paradigms are political and not comprehensive doctrines themselves. The inclusive conception, as portrayed by Brudner, is freestanding of Roman Catholicism or secular humanism. It is freestanding of transcendental idealism, moral realism, historical materialism, or any other metaphysical, metaethical, or sociological position one might suggest. Thus, if the liberal paradigms are political and not comprehensive doctrines, and if the consensus is likewise political and freestanding, Brudner's success in presenting a justification of the ideal liberal constitution that is at once philosophical and not freestanding, seems questionable. This doubt in turn raises the problem of the stability and legitimacy of the ideal liberal constitution.

\section{Constitutional Goods and the Problem of Reasonable Pluralism}

Rawls argues that one of the primary reasons he developed a political conception of justice as fairness was his recognition of the phenomena of reasonable pluralism in liberal societies. Rawls's claims that the exercise of reason under conditions of freedom will produce a variety of reasonable comprehensive doctrines, and that these cannot serve as the basis for a justification of a conception of justice. Rawls's arguments, as mentioned throughout this paper, turn on the notion that a conception of justice that is justified by Roman Catholics in virtue of Roman

22 n 1 above, 183-4. 
Catholic doctrine will not prove stable in a society composed of atheists, Buddhists, protestants, and so on. In the preceding discussion, I have argued that Brudner's characterisation of the justification of the ideal liberal constitution amounts to a public justification of a political conception of justice that is freestanding of comprehensive doctrines. A serious consequence of these arguments is that Brudner is now faced with the problem of providing an account of how his theory of justice and justification addresses the problem of reasonable pluralism. Brudner seems to have two options before him. The first would be to accept the thrust of these arguments and embrace a kind of public justification on the basis of public reason and the burdens of justice. The second would be to deny the phenomena of reasonable pluralism, or deny that the justification of the ideal liberal constitution is meant to address reasonable comprehensive views that fall outside the inclusive conception of liberalism. It seems to me that the relative costs weigh heavily in favour of the first option, as Brudner's concern with the portrayal of an ideal liberal constitution that embodies the constitutional goods he proposes can be recast in terms of a freestanding political conception of justice. The costs of the second option are to present a defence of the ideal liberal constitution that cannot provide the basis for a stable and legitimate polity in conditions of reasonable pluralism. However, even if Brudner adopts the second strategy, two further problems remain in his account of the justification of the ideal liberal constitution that threaten his proposed constitutional order, namely: the epistemology of a convergent consensus, and the reasonableness of the inclusive conception.

\section{INDETERMINACY, BURDENS OF JUDGMENT, AND THE CONVERGENT CONSENSUS}

We recall that Brudner characterised Rawls's view of an overlapping consensus as involving a commitment to the indeterminacy of judgment. Brudner claimed that Rawls's notion of an overlapping consensus on a political conception of justice was informed by the view that the burdens of judgment prevent agreement on the basis of any particular comprehensive doctrine. The burdens of judgment argument was derived from the view that due to imperfect information, subjective preference weighting, and the fuzziness of many moral and political concepts, judgment is necessarily indeterminate. As a consequence of the indeterminacy of judgment, agreement amongst reasonable citizens involves a commitment to the necessary constraints of the burdens on judgment. ${ }^{23}$ But Brudner argues that the problem of the indeterminacy of judgment and therefore the commitment to the burdens of judgment can be avoided by adopting an alternative view of judgment

23 Reasonable agreement also involves a commitment to an agreement on the basis of reasons and values that are authoritative to all. We will consider this point in the next section. 
where the conception of justice of each liberal paradigm is compared to a constitutional whole based entirely on that conception (what Brudner calls the concept of public reason). When a libertarian constitution fails to provide the kind of just order a libertarian themselves would accept, the argument moves to the next conception (egalitarianism) in order to remedy the problems with the concept of a libertarian constitution, and so on to communitarianism. However, there seem to be two problems with Brudner's discussion of judgement and the kind of consensus that follows: firstly, that Rawls's view is not based on the indeterminacy of judgment; and secondly, that Brudner's understanding of judgment allows of no consensus.

\section{INDETERMINACY AND INCONCLUSIVITY IN JUDGMENT}

Gerald Gaus points out '...talk of "indeterminacy" can easily lead us astray. Indeterminacy and inconclusiveness are distinct; a great deal of trouble is avoided if we see this clearly. ${ }^{24}$ Indeterminacy applies to judgments where there are no grounds to accept or reject a belief or proposition $(\beta)$. Inconclusiveness applies to judgments where there are grounds to accept of reject $\beta$, but these grounds are open to a degree of doubt or uncertainty due to lack of perfect information etc, and are therefore defeasible. As Gaus argues, this distinction points to a common intuitive difference in the use of these terms. ${ }^{25}$ It should be clear from this distinction that Rawls's burdens of judgment argument is derived from a view that judgments about reasonable comprehensive doctrines are inconclusive, certainly when applied to political questions. His view is not that these comprehensive doctrines are subject to the burden of indeterminacy. Indeed, it is as important feature of the reasonableness of a comprehensive doctrine that there be good grounds from within the doctrine for its adoption:

a reasonable doctrine is an exercise of theoretical reason: it covers the major religious, philosophical, and moral aspects of human life in a more or less consistent and coherent manner... It organises and characterizes recognized values so that they are compatible with one another and express an intelligible view of the world... it tends to evolve slowly in the light of what, from its point of view, it sees as good and sufficient reasons. ${ }^{26}$

The burdens of judgment are not therefore a result of the indeterminacy of judgment, but rather the inconclusivity of judgment. We might think that this is a mere terminological difference between Brudner and Rawls, and that Brudner's point remains if we swap the notion of indeterminate for inconclusive. However,

\footnotetext{
24 G. Gaus, Justificatory Liberalism (Oxford: Oxford University Press, 1996) 152, see also M. Swartzman, 'The Completeness of Public Reason' (2004) 3 Politics, Philosophy, and Economics 191 for employment of this distinction in defence of public reason.

25 Gaus, $n 24$ above, 153.

${ }^{26}$ Rawls, Political Liberalism, n 5 above, 59.
} 
even if this point can be addressed by terminological adjustment, there seems to me two reasons why Brudner cannot avoid the force of Rawls's burdens of judgment argument as fully as he suggests.

Firstly, Brudner's rejection of the burdens of judgment argument is derived from his rejection, or at least side-stepping, of the problem of indeterminacy. I have just argued that the burdens of judgment argument is derived from the problem of inconclusivity, and not indeterminacy. If Brudner believes that the inconclusivity ground can likewise be rejected or side-stepped, what does this mean for the status of the judgments that underpin the liberal paradigms and the inclusive conception? Are these immune from the burdens of judgment? Are there conclusive reasons to hold to libertarianism, egalitarianism, or communitarianism? Surely not, as these are superseded by the inclusive conception, and therefore each independently is subject to a qualification on its reasons, and therefore its reasons are neither conclusive nor indefeasible. If the liberal paradigms are not free of the burdens of judgment, perhaps the inclusive conception is. This seems more likely to be Brudner's position, but the implication of this is that there is no qualification on the justification of the inclusive conception. None of the reasons, beliefs, information, and weightings are inconclusive. This seems an implausibly high standard of justification for any conception of justice to attain. This objection to Brudner's position rests on the view that by conflating indeterminacy with inconclusivity, he has failed to show that the burdens of judgment do not apply. But perhaps Brudner need not meet this objection directly, but merely offer an alternative account of judgment that is superior. This he offers in his account of dialectical reasoning as an alternative to Rawls's account of judgment.

My second reason to doubt that Brudner can avoid the burdens of judgment argument is derived from the possibility of a public justification of a political conception of justice on the basis of dialectical reasoning. One of the conditions of Rawls's public reason, as constrained by the burdens of judgment, is that the modes of argumentation must be publicly accessible and not esoteric or controversial. Brudner gives an overview of dialectical reasoning in relation to libertarianism:

We do not ask, for example, whether cold mutual respect accords with (is an instance of) public reason as we understand it; rather, we ask whether it is public reason according to libertarianims's own understanding of that concept as excluding subjective preferences. And the answer depends on whether the conception of public reason as mutual cold respect conforms, when realized, to libertarianism's own understanding of what a public reason is or whether it dissolves into what it takes to be the opposite of a public reason. Here, therefore, it is not we who judge externally that the conception is deficient; it is rather the conception that reveals itself as deficient by its own standards 
just in the process of realizing itself. This, of course, is the kind of thinking that Plato and Hegel called dialectic... ${ }^{27}$

Can such an account of reasoning provide a basis for a public justification of the ideal liberal constitution? Rawls takes the view that modes of argumentation must be accessible to all in order for a just polity to be stable and legitimate. It seems to me that one hallmark of the kind of accessible thinking Rawls has in mind is that there is at least expert consensus on its nature and limits. This would apply to scientific reasoning, the methodology of which is well established, taught to children in schools, and part of the public discourse of media and politics. We can think of other modes that are similarly accessible and well established such as basic inferential, syllogistic, and deductive modes of reasoning. However, dialectical reasoning seems to me on a par with transcendental reasoning, or quantum logic. These modes of reasoning are historically well established, and subject of serious research programmes, but they are also highly contested and far from accepted as appropriate modes of public argumentation. Perhaps dialectical reasoning is much more common sense than I have suggested, and I confuse philosophical controversy with public controversy. In which case, dialectical reasoning may be allowed as a basis for public justification of the ideal liberal constitution. However, even if dialectical reasoning is an appropriate basis for public justification, it seems to me that it cannot provide the basis for a consensus of any kind, whether overlapping or convergent, because it does not provide the basis for an agreement between the paradigms.

\section{CONSENSUS AND EXCLUSION}

Brudner argues for a convergent consensus over an overlapping consensus. We have seen that the basis for this argument is the view that the overlapping consensus is based on an inappropriate model of judgment, and that it will collapse into a modus vivendi. Brudner is nevertheless committed to the view that justification of the ideal liberal constitution relies on consensus. The convergent consensus, as set out by Brudner, involves each liberal paradigm, through a process of dialectical reasoning, converging on the inclusive conception of liberalism as the fullest and most coherent conception of justice that provides each conception with its full realization. Brudner presents a deeply impressive dialectic from which the inclusive conception is produced. But it seems to me that this dialectical reasoning cannot produce a consensus. A consensus involves a mutual acceptance of the justificatory efficacy of certain reasons, beliefs, evidence etc. Brudner disagrees that consensus will be overlapping between a plurality of reasonable comprehensive views on a freestanding conception of justice, but he still aspires to a consensus between liberal paradigms on the inclusive conception. However, as Brudner has described the dialectical process of justification, it seems

27 n 1 above, 432. 
as if each liberal paradigm finds reasons for acceptance of the inclusive conception that are internal to their own conception. As quoted above, Brudner describes this as a process of self-comparison ${ }^{28}$ where it is '... the conception that reveals itself as deficient by its own standards just in the process of realizing itself.'29 However, whilst Brudner might have successfully shown how, through a process of dialectical reasoning, a libertarian can find the inclusive conception justified qua fulfilment of the libertarian paradigm (and so on for the other liberal conceptions), it doesn't seem as though any of the paradigms finds the inclusive conception justified on shared grounds. The egalitarian does not find the inclusive conception justified on the basis of the same reasons, beliefs, values, and evidence that the libertarian or communitarian finds them justified. This is because the egalitarian's dialectical justification refers to the incomplete realization of the ideal liberal constitution in an egalitarian constitution. The inclusive conception of liberalism is justified to the egalitarian because it realizes egalitarianism fully. There is no convergence of justifications between libertarians, egalitarians, and communitarians because each liberal paradigm provides its own exclusive justification. The libertarian does not find the inclusive conception justified because of its fulfilment of the egalitarian conception. We might explain the point formally: Brudner's argument states: $D \Leftrightarrow A^{\prime} \wedge B^{\prime} \wedge C^{\prime}$ where $D$ is the convergent consensus on the overlapping consensus, and where A', B', and C' represent the libertarian, egalitarian, and communitarian liberal paradigms respectively, as adjusted by the process of dialectical reasoning, $\wedge$ is conjunction, and $\Leftrightarrow$ is equivalence. However, according to my argument above: $A^{\prime} \underline{\mathrm{V}} \mathrm{B}^{\prime} \underline{\mathrm{V}} \mathrm{C}^{\prime}$ where $\underline{\mathrm{V}}$ stands for the exclusive disjunction 'or, but not both.' This represents the argument that the particular liberal paradigms justify the inclusive conception on their own terms (according the model of dialectical reasoning) and that each cannon of justification presented by a particular paradigm excludes the others because it draws on reasons and values that are at odds with the other liberal paradigms. We recall that in section $4 \mathrm{I}$ argued that a convergent consensus is unlikely because member liberal paradigms of the inclusive conception are composed of mutually exclusive doctrines, and there is no such thing as a coherent libertarian, egalitarian, or communitarian paradigm. There are therefore no liberal paradigms that can converge. My argument against the possibility of a convergent consensus may therefore be summarised formally as: $\mathrm{D} \Leftrightarrow\left\{\mathrm{A}_{1} \underline{\mathrm{V}} \mathrm{A}_{2} \underline{\mathrm{V}} \mathrm{A}_{3}\right\} \underline{\mathrm{V}}\left\{\mathrm{B}_{1} \underline{\mathrm{V}}\right.$ $\left.\mathrm{B}_{2} \underline{\mathrm{V}} \mathrm{B}_{3}\right\} \quad \underline{\mathrm{V}}\left\{\begin{array}{lllll}\mathrm{C}_{1} & \underline{\mathrm{V}} & \mathrm{C}_{2} & \underline{\mathrm{V}} & \mathrm{C}_{3}\end{array}\right\}$ where $\mathrm{A}_{1}$ is left-libertarianism, $\mathrm{A}_{2}$ is rightlibertarianism, and $\mathrm{A}_{3}$ is conscience-libertarianism, repeated for the other variants in the egalitarian and communitarian paradigms. This means that the convergent consensus $\left(D \Leftrightarrow A^{\prime} \wedge B^{\prime} \wedge C^{\prime}\right)$ is impossible. ${ }^{30}$ Brudner may respond that the convergent consensus is merely a model for the kind of relationship that exists between the different liberal paradigms in the inclusive conception, and that it

28 ibid, 431.

29 ibid, 432

30 Thank to Conrad Heilmann for discussion on this point. 
does not require that they find the ideal liberal constitution justified on the same grounds as each other, but that they find the same conception justified, according to their own reasons and values. But this seems to amount to a modus vivendi. One of the differences between a modus vivendi and consensus as principled agreement, is that a modus vivendi is an agreement based on a coordination of separate interests, whereas consensus is an agreement on shared reasons and values. A modus vivendi is in this respect a contract on the basis of mutual advantage, and not a contract on the basis of fairness and reciprocity. ${ }^{31}$ If, as I have argued, the various liberal paradigms do not find the ideal liberal constitution justified as a result of a convergence on a consensus of reasons and values, but rather find the ideal liberal constitution justified because of a coordination of separate interests, then Brudner's account of convergent consensus seems more susceptible to a collapse into modus vivendi than does Rawls's.

\section{BRUDNER'S UNREASONABLE AGREEMENT: PUBLICITY, RECIPROCITY, AND FAIRNESS}

I have argued above that Brudner's account of a convergent consensus rests on the view that each member paradigm of the inclusive conception of liberalism agrees to the conception of justice for reasons particular to each conception. I claimed that this amounted to a modus vivendi rather than a principled consensus. One of the implications of this argument is that the justification lacks important moral elements that are included in Rawls's notion of reasonableness, namely fairness and publicity. ${ }^{32}$ The notion of fairness is expressed in Rawls's view that citizens are motivated to seek agreement on terms of cooperation that are reciprocally acceptable to all; the notion of publicity is expressed in Rawls's view that assurance of fairness as the basis of agreement should be expressed publically.

The notion of fairness has two important dimensions: firstly that the citizens are motivated to engage in cooperative political and social relationships, and secondly that the principles that govern these relationships are justified to the extent that all cooperators regard them as fair. In other words, the principles are known to all, the mode of reasoning is accessible to all, and the values and justifications are shared by all. There is no appeal to any interest or source of reasoning that cannot be shared by all cooperators. Rawls describes this as the point of view of you and me, which is distinct from one of altruism or mutual advantage. ${ }^{33}$ Stephen Darwall has recently characterised this relationship as the

\footnotetext{
${ }^{31}$ See Rawls, Political Liberalism, n 5 above, 16-17.

32 Rawls says that reasonableness has two aspects '...the willingness to propose fair terms of cooperation and to abide by them provided others do. The second basic aspect... is the willingness to recognize the burdens of judgment and to accept their consequences for the use of public reason in directing the legitimate exercise of political power in a constitutional regime.' ibid, 54. Having considered the burdens of judgment argument, we are now considering the fairness argument.

33 ibid, 70 .
} 
second-person standpoint. ${ }^{34}$ A first-person reason is one that is based on the particular agent-relative interests of an individual, a third-person reason is based on agent-neutral considerations (such as aggregate welfare), whilst '[a] secondpersonal reason is one whose validity depends on the presupposed authority and accountability relations between persons and, therefore, on the possibility of the reason's being addressed person-to-person.' ${ }^{35}$ This matches Rawls's view that ' $[\mathrm{r}]$ easonable persons, we say, are not moved by the general good as such but desire for its own sake a social world in which they, as free and equal, can cooperate with other on terms all can accept. They insist that reciprocity should hold within that world so that each benefits along with others. ${ }^{36}$

Publicity is a dimension of reasonableness because it embodies mutual respect. Publicity embodies mutual respect because it shows that we value reciprocity in justification. Reciprocity in justification means that we expect others to openly and publically provide assurance that they endorse the agreement on the basis of shared reasons and values, and that we believe others are entitled to have assurance of our endorsement on these grounds. 'Insofar as we are reasonable, we are ready to work out the framework for the public social world, a framework it is reasonable to expect everyone to endorse and act on, provided others can be relied on to do the same. ${ }^{37}$ The public justification of a political conception of justice that is based on an overlapping consensus between reasonable citizens is a justification from the second-person standpoint. It refers to the authority of fair and public justification that applies over all reasonable citizens. This authority is grounded on principles and values that are recognised by all reasonable citizens on the same ground, and this reciprocal recognition itself provides part of the authority of these reasons.

When we turn to Brudner's rendering of the justification of the ideal liberal constitution, is it characterised by reasonableness in the same way? Does it include the values of fairness and publicity? It seems not. The justification of Brudner's ideal liberal constitution is provided by reasons particular to each liberal paradigm, as described in the discussion of dialectical reasoning and convergent consensus above. This model of justification seems to track the notion of a first-person standpoint, rather than a second-person standpoint. From the point of view of the libertarian, the egalitarian, and the communitarian, the ideal liberal constitution is justified because it realises most fully the moral commitments within each paradigm. The agreement is not constituted by fairness and publicity, because the reasons and values that justify the constitution are not shared. As there are no shared reasons, their authority cannot be second-personal, in the sense that they are mutually authoritative reasons. Consequently, a crucial element of the liberal notion of justice, namely fairness and the second-person standpoint, is absent

34 S. Darwall, The Second-Person Standpoint (Cambridge, Ma.: Harvard University Press, 2006).

35 ibid, 8 .

36 Rawls, Political Liberalism, n 5 above, 50 where the general good would be the third-person point of view.

37 ibid, 54. 
from Brudner's account. Therefore, the very account of justice embodied in the inclusive conception and the ideal liberal constitution, seems incompatible with the value of fairness that underlies the notion of a reciprocal justification of the authority of the conception. Absent fairness, we may ask what kind of justice and what kind of justification does Constitutional Goods provide? I have argued that even if problems with the possibility of agreement and consensus are overcome, the justification lacks the value of fairness and reasonableness. These values animate a liberal conception of justice, and many liberals will find any conception of justice that omits them less than ideal.

\section{CONCLUSION}

Brudner's conception of justice and justification is presented in large part in opposition to Rawls's political liberalism. I have argued that his suggested alternative of an inclusive conception of liberalism composed of dialectically refined liberal paradigms converging on a consensus is problematic. My most serious objections are that an inclusive conception may in fact be impossible, and even if the problems I raise can be surmounted, the agreement would not be characterised by the value of fairness. Such an agreement would amount to a modus vivendi and not a principled agreement on the basis of a shared commitment to the liberal confidence. Lacking fairness and consensus, Brudner's ideal liberal constitution seems unjustified. 